\title{
Travel Choice Component: Is The Price Important For Open Trip Tourists?
}

\author{
Ika Barokah Suryaningsih, Kristian Suhartadi Widi Nugraha, \\ and Deny Kurniawan Moelyadi \\ Faculty of Economics and Business, University of Jember, Jember \\ Email: barokah.feb@unej.ac.id
}

\begin{abstract}
This study aims to prove the role of price moderation in the travel choice component, namely the relationship of destination, accommodation, travel companions, and duration of open trip travel choice. The sample used was 120 tourists who travelled using an open trip package. The analysis in this study is a structural equation model (SEM-PLS) with a moderating effect using the SMARTPLS 03 software. The results showed that the destination, travel companion, and duration variables significantly influence travel tour choices. The accommodation has a negative coefficient but does not have a significant effect on travel choice. The price moderation coefficient also affects the strengthening of the relationship of destination, travel companions, and duration with travel choice. However, price moderation weakens the bond between accommodation and travel options.
\end{abstract}

Keywords: destination, accommodation, travel companion, duration, price.

\begin{abstract}
Abstrak: Penelitian ini bertujuan untuk membuktikan peran moderasi harga pada travel choice component yaitu hubungan tujuan, akomodasi, teman perjalanan, dan durasi pilihan perjalanan wisata open trip. Sampel yang digunakan adalah 120 wisatawan yang melakukan perjalanan menggunakan paket open trip. Analisis dalam penelitian ini adalah structural equation model (SEM-PLS) dengan efek moderasi menggunakan software SMARTPLS 03. Hasil penelitian menunjukkan bahwa variabel tujuan, teman perjalanan, dan durasi secara signifikan mempengaruhi pilihan perjalanan wisata. Akomodasi memiliki koefisien negatif, tetapi tidak berpengaruh signifikan terhadap pilihan perjalanan wisata. Koefisien moderasi harga juga mempengaruhi penguatan hubungan tujuan, teman perjalanan, dan durasi dengan pilihan perjalanan wisata. Namun demikian, moderasi harga justru melemahkan ikatan antara akomodasi dan pilihan perjalanan wisata.
\end{abstract}

\section{INTRODUCTION}

Indonesia's tourism potential is enormous, both from natural and cultural tourism. Indonesia has a diversity of cultures and beautiful natural scenery which makes Indonesia a local and foreign tourist destination visit. East Java is one of the provinces in Indonesia, which has attractive natural tourist destinations (Hamzah, 2013). This region offers a variety of natural attractions ranging from mountains, beaches, caves, to waterfalls and also artificial tours such as temples and museums.

In general, almost every regency or city in East Java has its leading destinations. The number of tourist destinations in the area of East Java, especially natural tourist destinations, 
especially mountains. The increasing development of tourism in East Java will also have an impact on the economic growth of businesses in East Java. According (Utama, 2017) tourism service businesses arise because of the various needs and needs of tourists that will encourage the growth of multiple types of other tourism service businesses so that the application of the business of travel agents is a business that is very suitable and needed by tourists visiting natural attractions, especially mountains.

Tourists who want to travel easily can use the services of a travel agency (Middleton and Clarke, 2001) because travel agents usually provide travel documents and accurate tourist information. The travel agency is a connecting bridge between tourists and accommodation service providers, restaurants, adventure tour information, tourism information and matters relating to tourism activities. Generally, tourists use the services of a travel agent in determining their travel plans by using an open trip package.

According to (Brahmanto, 2015; Pons, 2016), the open trip can be interpreted as a tour with one or more destination visits arranged from various specific travel facilities in a predetermined travel event. The making of tour packages is also balanced with the quality of human resources, in this case, the tour guide. Tour guides must always update or deepen their knowledge by updating their competencies. Tourists can explore the natural beauty and a variety of charming destinations following the time that tourists want. Open trips are much in demand by travelling lovers, where there is a minimum limit of participants causing the cost of travel to be cheaper (Jang and Moutinho, 2019). For lovers of travelling, an open trip is one solution that is very suitable for their journey.

Travel destinations are an essential part for businesses to be able to attract potential tourists. Tourist destinations that are very interested in travelling tourists can be measured through the increasing number of visitors each period, although the possibility of a dense road will not reduce the interest of tourists to visit (Apostolopoulou and Papadimitriou, 2015). Parameters that can be used as a benchmark for tourism objects are attractions, accessibility, infrastructure and facilities (Nawangsari et al., 2017; Suryaningsih and Sumani, 2018).

Evaluating and understanding consumer interest in services, especially tourism services, is not easy. Tourists, as consumers have different qualities. This difference is influenced by individual factors themselves and also by environmental factors that influence it (Matzler et al., 2016). This difference affects the interest and behaviour of consumers of tourism services in making the selection decision on the desired services. Therefore, some business people, namely travel service providers, at least implement particular strategies to be able to attract visitors. There are several components in carrying out the activity of a tour related to the attractiveness of consumers to use the services of tourism that have been provided. Things that can affect the level of attractiveness are service quality (Silvestri et al., 2017; Thai, 2008), price (Jang and Moutinho, 2019; Kim et al., 2019), and promotion (Susanto, A and T, S, M, 2017).

The selection of the right components by looking at cultural conditions (Matzler et al., 2016) must be balanced because this can affect the attractiveness of tourists to the package to be selected. Cultural diversity in each region is undoubtedly different, and this problem is complicated for the perpetrators of travel service providers to determine the components or package system strategies that attract tourists.

According to (Fesenmaier, 1995; Yuliandari, 2018), tourist decisions are the extent to which the benefits of a tourism product are felt under expectations. The choice of tourists is 
also a benchmark for travel agents to be able to improve their services, to get a positive response. That becomes a reference for potential customers to choose a travel agent. (Rizkiana and Kartini, 2017) in their study stated that the development and renewal of the service strategy system (Mukherjee et al., 2018) in the field of tourism is not only focused on evaluating performance to be better. It is due to the selection of components that fit criteria such as points of interest (Suryaningsih and Sumani, 2018), facilities obtained, travel companions and length of stay (Amzad et al., 2012; Chaulagain et al., 2019; Dellaert et al., 2012; Wang et al., 2009). These four components become specific strategies for tour operators so that they attract consumers to use open trip based services. The first approach that can be done by a service bureau is to use a plan to support tour leader services.

The role of strategic tour package components is decisive enough to provide consumer satisfaction (Amzad et al., 2012) to be able to attract interest and also the progress of the program of these open trip-based businesses. This study refers to the findings (Dellaert et al., 2012) that identify several variables, namely destination, accommodation, travel companion, duration, date control, multi-faceted tourist, to determine tourist choice. Various components that were revealed by Dellaert were later known as the Travel Choice Component (TCC). However, this study variable in this study uses the variables of destination, accommodation, travel companions, duration (Dellaert et al., 2012)and price (Jang and Moutinho, 2019; Kim et al., 2019) tourist decisions in choosing an open trip. Based on the background related to the phenomena and many previous research results, the purpose of this study is to prove the role of price moderation on destination, accommodation, travel companions, and duration relationships in tourist decisions in choosing Open Trip services.

\section{THEORETICAL REVIEW}

Destination. The influence of the destination on tourists' decisions in choosing open trip services is a meaningful relationship. Destination image (Gultom, 2017; Rahman et al., 2017; Suryaningsih and Sumani, 2018) becomes the most prominent influence to make the attraction of the tourist satisfaction (Silvestri et al., 2017) and loyalty (Hwang et al., 2019) because the image of the destination that is offered attracts the desire of tourists to visit. The selection of destinations with special interests will be a unique attraction to try so that there is a sense of curiosity with these attractions. Therefore, the hypothesis proposed is:

\section{H1: Destinations influence the Tourist Decision in Choosing Open Trip Services.}

Accommodation. According to (Utama, 2017)tourism facilities are facilities provided to tourists both directly and indirectly as a form of service. Tourism facilities and infrastructure include: transportation, travel agents, serviced accommodation, which is the accommodation that provides food and beverage facilities and services, and other facilities such as a souvenir shop and handicraft centre. According to (Kalebos, 2016), the quality of service ( $\mathrm{Ga}$ and $\mathrm{Sa}, 2005$ ) affects the satisfaction of tourists who visit (Silvestri et al., 2017). The quality of service in tourism services is accommodation (Dellaert et al., 2012; Suryaningsih and Sumani, 2018; Ye et al., 2019), so the second hypothesis in this study is:

H2: Accommodation Significantly Influences Tourist Decisions in Choosing Open Trip 
Services.

Travel Companions. The reference group, according to (Kotler and Keller, 2016) is a person or group that has a direct or indirect influence on the person's attitude or behaviour. (Sumarwan, 2002)States that the reference group is a point of direct comparison in determining the position of one's behaviour. A travel companion is a person or group that accompanies a tour, such as a partner, friend or family that can influence the interest in visiting tourist attractions. An essential component of travel is the influence of travel companions. According to (Dellaert et al., 2012; Durko and Stone, 2017; Fitriyah, 2013) there is an influence of the reference group and family variables (Merrilees and Miller, 2019) on decisions. Thus, the third hypothesis is:

H3: travel companions significantly influence tourists' decisions in choosing Open Trip services.

Duration. The duration of the trip is the time required in open trip tourism activities. The period of the vehicle is adjusted to the destination (Fesenmaier, 1995). Tourists face several types of time constraints; for example, the length of the trip may depend on the school vacation schedule, work, and schedule of their travel companions. According to (Dellaert et al., 2012) the duration variable on the multifunctional component applied to measure tourist satisfaction (Chang and Thai, 2016; Hsu et al., 2020; Thai, 2015) influence the decision of a tour so that duration makes one of the components that can affect the decision to choose. Therefore the fourth hypothesis is:

H4: duration significantly affects tourists' decisions in choosing Open Trip services.

Price. The selection and decision of the tour cannot be separated from the influence of prices (Kim et al., 2012; Kim et al., 2019). According to (Sirait and Puddin, 2018), the effect of prices on tourist visiting decisions has a positive impact. However, under certain conditions, prices can be a factor that reinforces decisions, but can also weaken conclusions (Drozdenko and Jensen, 2009; Jang and Moutinho, 2019; Kim et al., 2019; Swani and Yoo, 2010). Based on previous research, the price becomes a moderating variable in this study. The fifth hypothesis is:

H5a-d: Prices moderate the relationship of destination, accommodation, travel companions, and duration of the decision of tourists in choosing Open Trip services.

Based on the background and theoretical review, the conceptual framework of the study can be seen in Figure 1. 
Figure1. Conceptual Framework

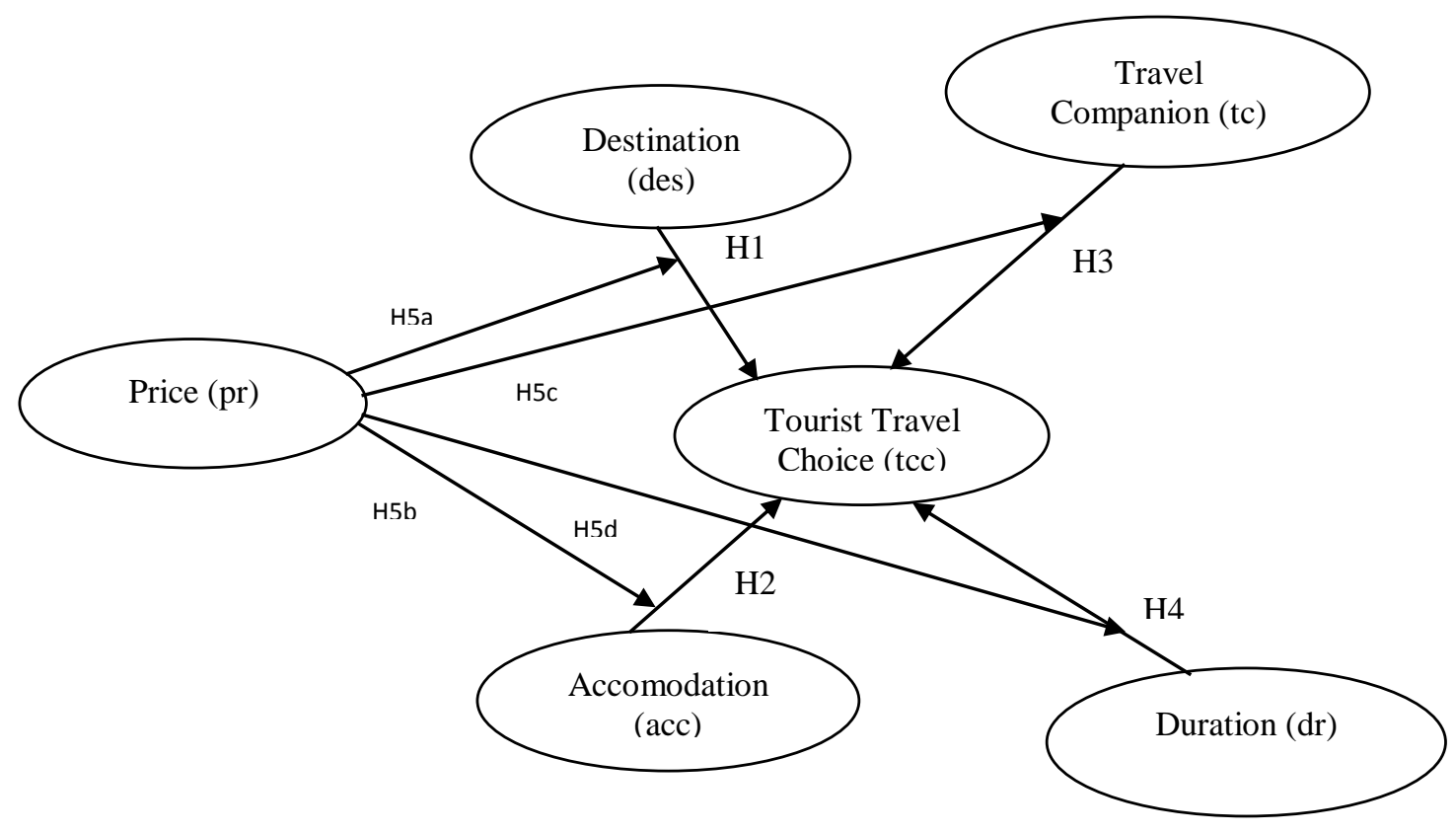

\section{METHODOLOGY}

This research was conducted using an explanatory research approach to know the role of price moderation on the travel choice component (TCC) consisting of destinations, accommodations, travel companions, and duration (Dellaert et al., 2012) of the decision of tourists (Gao et al., 2012; Insch et al., 2011; Rahman et al., 2017) choosing an open trip tour package.

This type of quantitative research, because the data obtained later in the form of data that has the characteristics of a variable whose values are expressed in numerical form using a Likert scale from 1 (strongly disagree) to 5 (strongly agree). Data collection tool is done by using a questionnaire.

The analysis in this study uses a structural equation model (SEM-PLS) that can correct measurement errors by including the effect of interactions in the model (Hamid, 2019) with the SMARTPLS 03 software. SEM-PLS is used to test the estimation and significance of the Resampling (Bootstrap) method. The purpose of SEM-PLS Estimation is to make the best score component of endogenous variables, in this case, is the tourist travel choice variable. Also, SEM-PLS is used to predict the relationship between variables and indicators through the inner model, namely the relationship between latent variables and the outer model, namely the relationship between indicators and their latent variables (Ghozali, 2017).

Population and Sample. The object of this study is BroBet's open trip provider service. Based on observations of existing data, the number of open trip participants from February to October 2019 totalled 120 tourists. It is because of Open Trip Brobet's relatively new stand in line with the development of new tourism model trends. Based on the opinion (Arikunto, 2002) and (Sugiyono, 2016) where if the sample is less than 100 then it is taken as a whole, so the determination of the sample taken for this study is 120 tourists who have 
travelled from various regions that have to use the open trip tour package.

\section{THE RESULTS OF STATISTICAL TESTS}

Validity test. Evaluation of model measurements is done by looking at the outer model through the results of construct validity consisting of convergent validity and Average Varian Extracted (AVE) values. The results of data validity testing conducted using SMARTPLS 03 can be seen in Table 1

Table 1. Validity Test Results

\begin{tabular}{|c|c|c|c|c|}
\hline Variable & Items & $\begin{array}{l}\text { Loading } \\
\text { Factor }\end{array}$ & AVE & Description \\
\hline \multirow{3}{*}{$\begin{array}{l}\text { Destinatio } \\
\mathrm{n} \text { (des) }\end{array}$} & Strategic location (des1) & 0,897 & \multirow[t]{3}{*}{0,871} & Valid \\
\hline & Easy to reach (des2) & 0,896 & & Valid \\
\hline & Attractiveness (des3) & 0,896 & & Valid \\
\hline \multirow{4}{*}{$\begin{array}{l}\text { Accommo } \\
\text { dation } \\
(\text { acc) }\end{array}$} & Expected transportation (acc1) & 0,860 & \multirow[t]{4}{*}{0,854} & Valid \\
\hline & Information service facilities (acc2) & 0,832 & & Valid \\
\hline & Facilities (acc3) & 0,850 & & Valid \\
\hline & Food menu (acc4) & 0,818 & & Valid \\
\hline \multirow{3}{*}{$\begin{array}{l}\text { Travel } \\
\text { Companio } \\
\text { n (tc) }\end{array}$} & Close friends (tc1) & 0,937 & \multirow[t]{3}{*}{0,933} & Valid \\
\hline & Family (tc2) & 0,913 & & Valid \\
\hline & Himself (tc3) & 0,941 & & Valid \\
\hline \multirow{2}{*}{$\begin{array}{l}\text { Duration } \\
\text { (dr) }\end{array}$} & Timing selection $(\mathrm{dr} 1)$ & 0,901 & \multirow[t]{2}{*}{0,930} & Valid \\
\hline & Duration (dr2) & 0,915 & & Valid \\
\hline \multirow[t]{2}{*}{ Price $(\mathrm{pr})$} & Price suitability (pr1) & 0,923 & \multirow[t]{2}{*}{0,931} & Valid \\
\hline & Discount offer (pr2) & 0,927 & & Valid \\
\hline \multirow{3}{*}{$\begin{array}{l}\text { Tourist } \\
\text { Travel } \\
\text { Choice } \\
\text { (tcc) }\end{array}$} & Travel agency (tcc1) & 0,887 & \multirow[t]{3}{*}{0,883} & Valid \\
\hline & Program implementation (tcc2) & 0,911 & & Valid \\
\hline & $\begin{array}{l}\text { A positive response from previous } \\
\text { tourists (tcc } 3 \text { ) }\end{array}$ & 0,869 & & Valid \\
\hline
\end{tabular}

Source: (data processed, 2019)

Table 1 shows the validity test on all variables, to find out whether the variable is valid or not. Destination variable (des) which is divided into three indicators, namely strategic location (des1) has a loading factor value of 0.897 ; easy to reach object indicator (des2) has loading factor value of 0.896; and attractiveness indicator (des3) has loading factor value of 0.896. It shows that each indicator on the destination variable (des) has a loading factor 
value greater than 0.6. Thus, all constructing indicators for destination variables can be categorized as valid.

In the accommodation variable (acc) which is divided into four indicators namely expected transportation (acc1) has loading factor value of 0.860 ; an indicator of information service facilities (acc2) has loading factor value of 0.832 ; supporting facilities indicator (acc3) has loading factor value of 0.850 , and the food menu indicator obtained (acc4) has a loading factor of 0.818 . It shows that each indicator on the accommodation variable (acc) has a loading factor value greater than 0.6. Thus, all constructing indicators for accommodation variables can be categorized as valid.

Travel companion variable (tc) which is divided into three indicators, namely travel with close friends (tc1) has loading factor value of 0.937; an indicator of travel with family (tc2) has loading factor value of 0.913, and the trip indicator himself (tc3) has a calculated value of 0.941 . It shows that each indicator on the travel companion variable (tc) has a loading factor value greater than 0.6. Thus, all constructing indicators for travel companion variables can be categorized as valid.

The results of the validity test on the duration variable (dr) which is divided into two namely the timing selection indicator ( $\mathrm{dr} 1)$ have loading factor value of 0.901 and a trip length indicator (dr2) have a calculated amount of 0.915 . It shows that each indicator on the duration variable $(\mathrm{dr})$ has a loading factor value greater than 0.6 . The results of the validity test on the price variable (pr) which is divided into two namely price suitability indicator (pr1) have loading factor value of 0.923 , and a discount offer indicator (pr2) has loading factor value of 0.927 . It shows that each indicator on the price variable (pr) has a loading factor value greater than 0.6. Besides, the decision variable chooses BroBet's open trip (tcc) which is divided into three indicators: the travel agency (tcc1) has a calculated value of 0.887; program implementation indicator (tcc2) has loading factor value of 0.911 , and the positive response from previous tourist's indicator (tcc3) has a loading factor of 0.896 . It shows that each indicator on the tourist travel choice variable (tcc) has a loading factor value greater than 0.6. Thus, all constructing indicators for the duration, price, and tourist travel choice can be categorized as valid

Reliability Test. Reliability testing is done by finding composite reliability numbers on statement items in the questionnaire with alpha item standards. After the alpha value and composite reliability is known, a comparison is made with that value with a predetermined amount.

Table 2. Composite Reliability Test Results

\begin{tabular}{l|c|c|c|c}
\hline \multicolumn{1}{c|}{ Variable } & Cronbach's $\boldsymbol{\alpha}$ & $\begin{array}{c}\text { Composite } \\
\text { Reliability }\end{array}$ & $\begin{array}{c}\text { Critical } \\
\text { value }\end{array}$ & Description \\
\hline Destination (des) & 0,876 & 0,887 & 0,60 & Reliable \\
\hline Accommodation (acc) & 0,861 & 0,874 & 0,60 & Reliable \\
\hline Travel Companion (tc) & 0,933 & 0,939 & 0,60 & Reliable \\
\hline Duration (dr) & 0,865 & 0,876 & 0,60 & Reliable \\
\hline Price (pr) & 0,830 & 0,843 & 0,60 & Reliable \\
\hline
\end{tabular}




\begin{tabular}{l|c|c|c|c}
\hline $\begin{array}{l}\text { Tourist Travel Choice } \\
\text { (tcc) }\end{array}$ & 0,867 & 0,878 & 0,60 & Reliable \\
\hline
\end{tabular}

Source: (data processed, 2019)

Table 2 shows that the Cronbach- $\alpha$ and composite reliability value of each variable is greater than the determined critical reliability value (Ghozali, 2016). The destination variable (des) has a value of $0.887>0.60$; accommodation variable (acc) has a value of $0.874>0.60$; travel companion variable (tc) has a value of 0.939>0.60; The duration variable $(\mathrm{dr})$ has a value of $0.876>0.60$ The price as moderating variable (pr) has a value of $0.843>0.60$ and the decision variable (tcc) has a value of 0.878>0.60. Based on these data, it can be concluded if all items on the statement in the questionnaire are reliable or trustworthy so that the construct of exogenous variables towards endogenous with moderating effects can be said to be reliable (Hamid, 2019).

Structural Testing Results (Inner Model). SEM-PLS is determined the level of influence of exogenous variables (destination, accommodation, travel companions, duration, price) on the endogenous variable (tourists' decision to use BroBet's open trip), structural equation model (SEM-PLS) analysis was performed. The results of the SEM-PLS can be seen in Table 3. The equations of SEM-PLS with moderating effect are as follows:

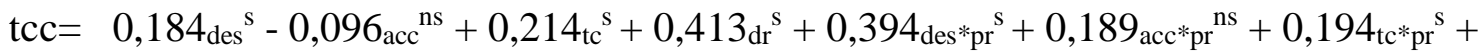

$$
\begin{aligned}
& 0,313 \mathrm{dr}^{*} \mathrm{pr}^{\mathrm{s}}+\zeta
\end{aligned}
$$

Note:

des $=$ destination

acc $=$ accommodation

tc $=$ travel companion

$\mathrm{dr}=$ duration

$\mathrm{pr}=$ price

tcc $=$ tourist travel choice

$\zeta=$ error

The coefficient in the model is the magnitude of the contribution of destination, accommodation, travel companion, duration, the role of price moderation, to tourist travel choice in choosing the open trip. Variable destination, travel companion, and duration significantly affect tourist travel choice.

Nevertheless, the accommodation has a negative coefficient, but no significant effect on tourist travel choice. The price moderation coefficient also influences strengthening the relationship of destination, travel companion, and duration with tourist travel choice. Thus, price moderation precisely weakens the bond between accommodation and tourist travel choices. The detailed results of the SEM-PLS analysis testing are presented in table 3. 
Table 3. The Path Coefficients and Hypothesis Testing Results

\begin{tabular}{l|c|c|c|l}
\hline \multicolumn{1}{c|}{ Model } & $\begin{array}{c}\text { Path } \\
\text { Coefficients }\end{array}$ & t-statistic & p-value & Description \\
\hline Destination & 0,184 & 2,167 & 0,034 & H1 accepted \\
\hline Accommodation & $-0,096$ & $-1,359$ & 0,180 & H2 rejected \\
\hline Travel Companion & 0,214 & 2,463 & 0,017 & H3 accepted \\
\hline Duration & 0,413 & 2,983 & 0,004 & H4 accepted \\
\hline Destination* Price & 0,394 & 2,723 & 0,009 & H5a accepted \\
\hline Accommodation* Price & 0,189 & 2,059 & 0,068 & H5b rejected \\
\hline Travel Companion* Price & 0,194 & 2,263 & 0,021 & H5c accepted \\
\hline Duration* Price & 0,313 & 2,883 & 0,006 & H5d accepted \\
\hline Sourc: (data processed 2019) & & & &
\end{tabular}

Source: (data processed, 2019)

Based on the test results obtained SEM-PLS Analysis coefficient and hypothesis testing. Table 3 shows that $\mathrm{H} 1, \mathrm{H} 3$, and $\mathrm{H} 4$ were accepted, while $\mathrm{H} 2$ was rejected. The role of price moderation provides a picture of the same results that $\mathrm{H} 5 \mathrm{a}, \mathrm{H} 5 \mathrm{c}$, and $\mathrm{H} 5 \mathrm{~d}$ are accepted while H5b is rejected. Model of the test results is clearly presented in Figure 2 below. 
Figure2. Model of the test results

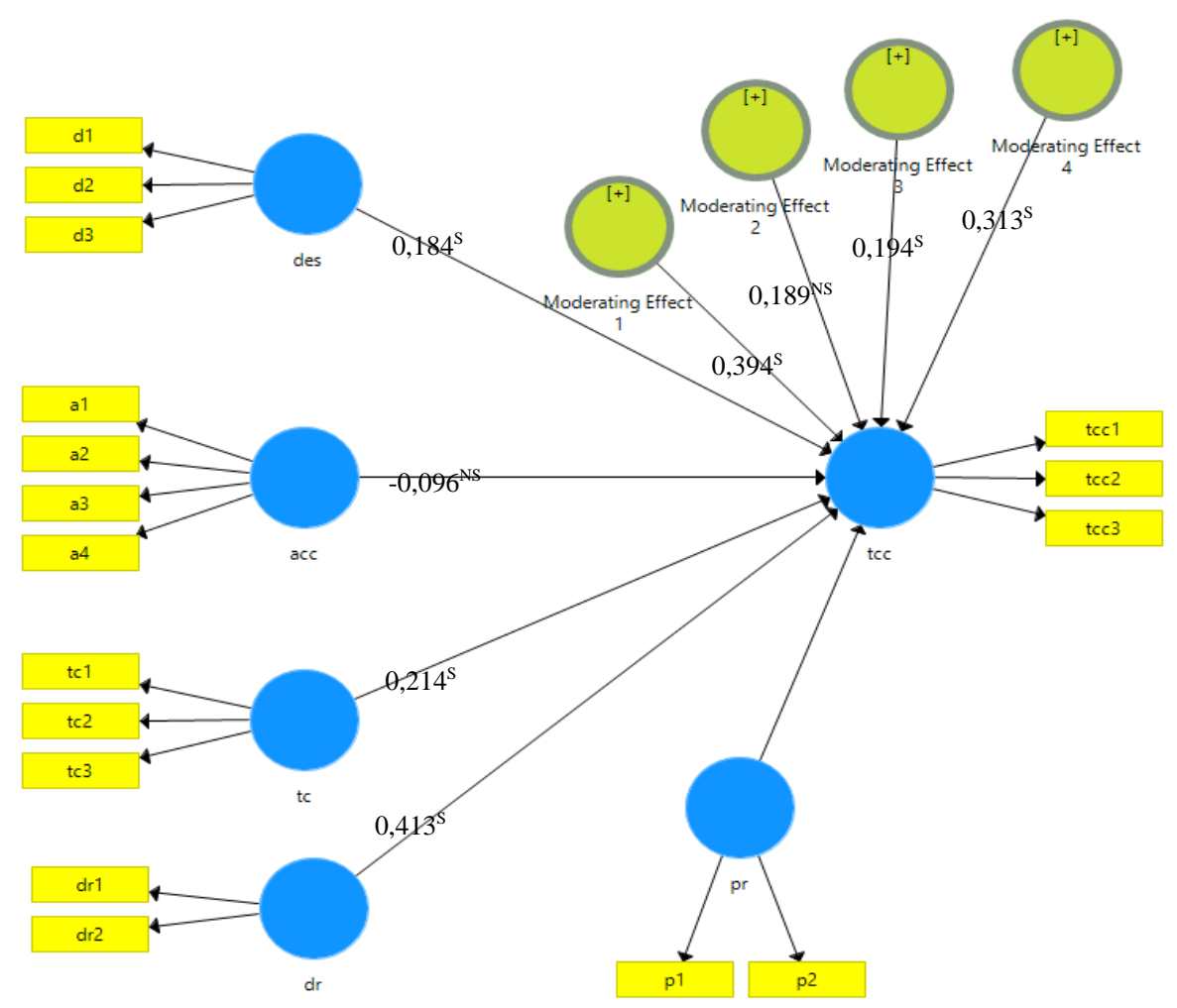

\section{DISCUSSION}

Influence of Destinations on tourist travel choice. Based on the research results, the destination has a positive impact on the decision of tourists to choose BroBet's open trip. The results of this study reinforce the findings (Hanif et al., 2016), which prove the positive influence of destination variables on tourist decisions. The results of this study also enhance the results of the survey (Mukherjee et al., 2018; Ratna et al., 2012; Suryaningsih and Sumani, 2018) prove that the destination image is considered good, so the destination variable has an influence on visitor decisions. The results of this study mean that the more popular destinations offered to potential tourists (Chaulagain et al., 2019), the higher the level of tourist visits and vice versa (Amzad et al., 2012; Gultom, 2017; Wang and Chen, 2004; Wang et al., 2009).

Destination variable, it is known that the majority of respondents gave a score agreeing on the indicators provided namely strategic places (Lyons et al., 2009), easily accessible objects (Hamzah, 2013), and attractiveness (Daoudi, 2000). It shows that the favourite destinations are many visits from various tourists and if offered to potential tourists will be an attraction to visit. This condition indicates if the indicators used in this study are under the first terms in the field. 
Effect of Accommodation on tourist travel choice. Tourism accommodation is facilities that will be obtained by tourists and companies that provide services to tourists both directly and indirectly (Utama, 2017). Accommodation (Ye et al., 2019) in this activity is a means that tourists will get in an open trip activity. However, the results of this study indicate that the accommodation variable does not affect the decision of tourists choosing the open trip. Tourists who have used BroBet's open trip tour package responded poorly to the indicators that had been submitted to 120 respondents.

The accommodation has a negative effect, so the results obtained are not the same as previous studies on the influence of accommodation that influence tourist decisions (Suryaningsih and Sumani, 2018). Thus, the hypothesis in this study rejects the opinions of (Sirait and Puddin, 2018) and also the views of (Kalebos, 2016) that is, an increase in facilities will affect the decision of tourists to visit tourist attractions.

Indicators of accommodation (Suryaningsih and Sumani, 2018; Ye et al., 2019) consist of transportation (acc1), service facilities (acc2), supporting facilities (acc3), and food menu (acc4). In this study shows that accommodation is not the primary concern of tourists in Brobet's open trip activities as it is known that open trip is just one special interest tour (Utama, 2017). Furthermore, if the consumption indicator is given as a fancy menu, the response of tourists is not so good. Tourists participating in Open Trips as special interest tours only emphasize the amount of calorie content needed rather than the menu variations (Wahidin and Purnhagen, 2018). Means have been criticized that transportation facilities do not need to be too fancy, quite simple but arrive at the destination safely (Eraqi, 2006). It is a new finding that individual interest service products have a unique segmentation as well so that tourists participating in open trips are more interested in tourist destination attractions than accommodations.

The influence of travel companions on tourist travel choices. The reference group is a direct comparison point in shaping one's behaviour (Sumarwan, 2002). The reference group (Kotler and Keller, 2016) in this study is equated with a travel companion because it has the same meaning and results. The results of this study prove those travel companions (Durko and Stone, 2017; Merrilees and Miller, 2019) influence tourist decisions.

Based on the results of responses about the variable travel companion for tourists who have used BroBet's open trip gave an excellent response to existing indicators. Travel activities with close friends will be more fun. Also, respondents gave right answers to the statement that travel with family would be safer and more comfortable because they felt they could protect one another. It provides the conclusion that the more comfortable friends and family are accompanying it, the more comfortable tourists are to travel with this type of open trip. These results support research conducted by (Fitriyah, 2013) with the results of the reference group (Atilgan et al., 2003) having a significant effect on purchasing decisions (Durko and Stone, 2017).

The Effect of Duration on tourist travel choice. The actual planning process and travel dates are made early in the planning process, on average, 6 to 7 months before the exact travel date (Fesenmaier, 1995). The duration of the trip in this open trip activity must be adjusted to natural conditions, namely the travel field from post 1 to the desired destination. The phenomenon that is seen is that if the duration while doing activities must adjust to the natural conditions that will be addressed so that the length of the climb can measure the 
tourist activity of open participant's trip.

Furthermore, the travel time selection indicator also has a strong influence on tourist travel choices (Lyons et al., 2009), especially if the participant is a worker or student who is currently studying. Placement time for BroBet's open trip activities to choose days off (Lyons et al., 2009) is an attraction for the student segment or workers to be able to travel without disturbing workers (Dellaert et al., 2012).

It becomes a conclusion if the timing and duration of the open trip activities must be adjusted to the market segment. These results support the opinion of a study made by (Dellaert et al., 2012) which gives positive effects on customer decisions with the time or duration of travellers' trips that have been agreed so that the length of the journey is sufficient. It shows that the phenomenon that can be obtained is the duration and timing that are offered to potential tourists will trigger an attraction to visit this indicates if the indicators used in this study are by the primary conditions in the field.

The Effect of Price moderation on tourist travel choice. Prices (Kotler and Keller, 2016) in these open trip activities are always listed on posters that have been distributed so that potential tourists can know them. The results of this study indicate that prices affect tourist travel choice (Jang and Moutinho, 2019; Swani and Yoo, 2010). Based on the response of tourists who have used BroBet's open trip, it gives an excellent answer to the indicators of price suitability and discounts (Swani and Yoo, 2010).

The price moderation coefficient also influences strengthening the relationship of destination, travel companion, and duration with tourist travel choices (Dellaert et al., 2012; Kim et al., 2019). The results of this study also support the research conducted by (Sirait and Puddin, 2018), namely the suitability of prices has a positive effect on visitor decisions. Thus, price moderation weakens the relationship between accommodation and tourist travel choices. This is because the effect of accommodation directly has no effect on the selection of open trip service providers. Tourism in this study is an open trip for special interest tourism which is more inclined to travelling back to nature so that tourists are more concerned with the attractiveness of destinations, travel companions, and length of travel.

Price suitability and discount offers as price proxies become unnoticed when these tourists choose special interest tours whose destination is attractive and increases adrenaline. Of course, tourists in this segment, tend choosing destinations as adventuring rather than focusing on the means of transportation used, luxury travel services, and even the food menu provided.

However, the moderating effect of price suitability and discount offer will be very influential if associated with tourist destinations, travel companions, and duration of time in travelling.

Therefore, price is an essential factor in tourist decisions in choosing an open trip. The open trip is included in the category of special interest tourism which is generally influenced by the tourist's preference for special tourism. However, the findings in this study price play an essential role as a moderating variable that strengthens tourists' decision to choose an open trip tour package. 


\section{CONCLUSION}

Destinations affect tourist travel choice. It means that one of the reasons for joining an open trip is the destinations offered, the attractions offered and the potential what tourists want to see. Different things have found in the effect of accommodation on tourist travel choices. The calculation results show that the accommodation variable does not affect tourist travel choice; this is because of the focus of open trips to tourist destinations while open trip accommodations are generally for backpacker tourists. In the third variable, tourist travel choice is influenced by travel companion, which means travelling companions who will also affect the decision to choose open trip activities. Travel companions can interpret as tourists will share the fun and challenges with tourists who have the same destination. Likewise, the duration of an open trip affects tourist travel choices. Tourists need to set the time and schedule so that it does not clash between travelling with work so that the duration becomes one of the essential points. Prices as a moderating variable affect destination, travel companions and durations but do not affect the accommodation.

Based on research that has been done and explained by researchers, some suggestions can be given, namely for businesses, namely BroBet's in increasing its marketing activities related to open trip tour packages, paying more attention to prices. The influence of variable accommodation which is inversely related to tourist travel choice must be the primary consideration in making marketing strategies considering that this type of tour is a special interest tour. For researchers, alternative alternatives for adding new variables or using other analytical tools such as SEM can be done.

\section{REFERENCES}

Amzad, M., Sarker, H., Candidate, P., Aimin, W., and Begum, S. (2012). Investigating the Impact of Marketing Mix Elements on Tourists 'Satisfaction: An Empirical Study on East Lake. European Journal of Business and Management, 4(7), 2222-2839.

Apostolopoulou, A., and Papadimitriou, D. (2015). The role of destination personality in predicting tourist behaviour: implications for branding mid-sized urban destinations. Current Issues in Tourism, 18(12), 1132-1151. https://doi.org/10.1080/13683500.2013.878319.

Arikunto, S. (2002). Metodologi Penelitian. PT. Rineka Cipta.

Atilgan, E., Akinci, S., and Aksoy, S. (2003). Mapping service quality in the tourism industry. Managing Service Quality: An International Journal, 13(5), 412-422. https://doi.org/10.1108/09604520310495877.

Brahmanto, E. (2015). Magnet Paket Wisata Dalam Menarik Kunjungan Wisatawan Asing Berkunjung Ke Yogyakarta. Jurnal Media Wisata, 13(2), 338-342.

Chang, C., and Thai, V. V. (2016). Do Port Security Quality And Service Quality Influence Customer Satisfaction And Loyalty? 8839(March). https://doi.org/10.1080/03088839.2016.1151086.

Chaulagain, S., Wiitala, J., and Fu, X. (2019). The impact of country image and destination image on US tourists' travel intention. Journal of Destination Marketing and Management, 12(January), 1-11. https://doi.org/10.1016/j.jdmm.2019.01.005.

Daoudi, M. (2000). Tourism and Hospitality Marketing. In Journal of Visual Languages \& Computing (Vol. 11, Issue 3). 
Dellaert, B. G. C., Ettema, D. F., and Lindh, C. (2012). Multi-faceted Tourist Travel Decisions: A constraint-Based Conceptual Framework To Describe Tourists' Sequential Choices Of Travel Components. Tourism Management, 19(4), 9-20. https://doi.org/10.4324/9780080519449-6.

Drozdenko, R., and Jensen, M. (2009). Pricing strategy \& practice: Translating country-oforigin effects into prices. Journal of Product and Brand Management, 18(5), 371378. https://doi.org/10.1108/10610420910981855.

Durko, A. M., and Stone, M. J. (2017). Even lovers need a holiday: Women's reflections of travel without their partners. Tourism Management Perspectives, 21, 18-23. https://doi.org/10.1016/j.tmp.2016.11.001.

Eraqi, M. I. (2006). Tourism services quality (TourServQual) in Egypt: The viewpoints of external and internal customers. Benchmarking, 13(4), 469-492. https://doi.org/10.1108/14635770610676308.

Fesenmaier, D., A. (1995). Examination Of The Complex Tourism Decision Making Process.

Fitriyah, N. (2013). Pengaruh Kelompok Acuan Dan Keluarga Terhadap Keputusan Pembelian Batik Tulis Jetis Pada Toko Amri Jaya Sidoarjo.

Ga, J. C., and Sa, M. (2005). Effects of service quality dimensions on behavioural purchase intentions. 1991. https://doi.org/10.1108/09604520710735164.

Gao, J., Zhang, C., Wang, K., and Ba, S. (2012). Understanding online purchase decision making: The effects of unconscious thought, information quality, and information quantity. Decision Support Systems, 53(4), 772-781. https://doi.org/10.1016/j.dss.2012.05.011.

Ghozali, I. (2016). Aplikasi Analisis Multivariate denganProgram IBM SPSS 23 (VIII). Badan Penerbit Universitas Diponegoro.

Ghozali, I. (2017). Model Persamaan Struktural Konsep dan Aplikasi dengan Program AMOS 24 ( $7^{\text {th }}$ ed.). Badan Penerbit Universitas Dipenegoro.

Gultom, D, K. (2017). Pengaruh Bauran Pemasaran Jasa Terhadap Citra Destinasi dan Keputusan Wisata Serta Implikasi Terhadap Loyalitas Wisatawan. Lembaga Penelitian Dan Penulisan Ilmiah, 1(2), 139-150.

Hamid, R. (2019). STRUCTURAL EQUATION MODELING ( SEM ) BERBASIS VARIAN Konsep Dasar dan Aplikasi Program Smart PLS 3 . 2 . 8 dalam Riset Bisnis (Issue February). Pt. Inkubator Penulis Indonesia.

Hamzah, Y. I. (2013). Potensi Media Sosial Sebagai Sarana Promosi Interaktif Bagi Pariwisata Indonesia. Jurnal Kepariwisataan Indonesia, 8(3), 1-9.

Hanif, Andriani, K. M., and Kholid, M. (2016). Pengaruh Citra Destinasi Terhadap Kepuasan Wisatawan Serta Dampak Terhadap Loyalitas Wisatawan. Jurnal Administrasi Bisnis, 3(1), 38.

Hsu, C. Y., Chen, M. Y., Nyaupane, G. P., and Lin, S. H. (2020). Measuring sustainable tourism attitude scale (SUS-TAS) in an Eastern island context. Tourism Management $\begin{array}{lll}\text { Perspectives, } & \text { 33(November } & \end{array}$ https://doi.org/10.1016/j.tmp.2019.100617.

Hwang, E., Baloglu, S., and Tanford, S. (2019). Building loyalty through reward programs: The influence of perceptions of fairness and brand attachment. International Journal of Hospitality Management, 76(May 2017), 19-28. https://doi.org/10.1016/j.ijhm.2018.03.009. 
Insch, A., Prentice, R. S., and Knight, J. G. (2011). Retail buyers' decision-making and buy national campaigns. Australasian Marketing Journal, 19(4), 257-266. https://doi.org/10.1016/j.ausmj.2011.07.003.

Jang, S., and Moutinho, L. (2019). Do Price Promotions Drive Consumer Spending On Luxury Hotel Services? The Moderating Roles Of Room Price And User-Generated Content. International Journal of Hospitality Management, 78. https://doi.org/10.1016/j.ijhm.2018.11.010.

Kalebos, F. (2016). Faktor-Faktor Yang Mempengaruhi Kepuasan Wisatawan yang Berkunjung Ke Daerah Wisata Kepulauan. Jurnal Riset Bisnis Dan Manajemen, 4(3), 489-502.

Kim, H. W., Xu, Y., and Gupta, S. (2012). Which is more important in Internet shopping, perceived price or trust? Electronic Commerce Research and Applications, 11(3), 241-252. https://doi.org/10.1016/j.elerap.2011.06.003.

Kim, J., Cui, Y. G., Choi, C., John, S., and Marshall, R. (2019). The influence of preciseness of price information on the travel option choice. Tourism Management, February, 104012. https://doi.org/10.1016/j.tourman.2019.104012.

Kotler, P., and Keller, K. L. (2016). Marketing Management 15 Global Edition. https://doi.org/10.1080/08911760903022556.

Lyons, S., Mayor, K., and Tol, R. S. J. (2009). Holiday destinations: Understanding the travel choices of Irish tourists. Tourism Management, 30(5), 683-692. https://doi.org/10.1016/j.tourman.2008.10.024.

Matzler, K., Strobl, A., Stokburger-Sauer, N., Bobovnicky, A., and Bauer, F. (2016). Brand Personality And Culture: The Role Of Cultural Differences On The Impact Of Brand Personality Perceptions On Tourists' Visit Intentions. Tourism Management, 52, 507520. https://doi.org/10.1016/j.tourman.2015.07.017.

Merrilees, B., and Miller, D. (2019). Companion Shopping: The Influence On Mall Brand Experiences. Marketing Intelligence and Planning, 37(4), 465-478. https://doi.org/10.1108/MIP-08-2018-0340.

Middleton, V., and Clarke, J. R. (2001). Marketing in Travel Tourism. 487.

Mukherjee, S., Adhikari, A., and Datta, B. (2018). Quality of Tourism Destination - A Scale Development. Journal of Indian Business Research, 10(1), 70-100. https://doi.org/10.1108/JIBR-07-2017-0104.

Nawangsari, D., Muryani, C., and Utomowati, R. (2017). Pengembangan Wisata Pantai Desa Watu Karung Dan Desa Sendang Kabupaten Pactan Tahun 2017. Jurnal GeoEco, 4(1), 31-40.

Pons, P. O. (2016). Cultures of Mass Tourism. In Cultures of Mass Tourism. https://doi.org/10.4324/9781315575568.

Rahman, M. S., Osman-Gani, A. M., and Raman, M. (2017). Destination selection For Education Tourism: Service Quality, Destination Image And Perceived Spirituality Embedded Model. Journal of Islamic Marketing, 8(3), 373-392. https://doi.org/10.1108/JIMA-10-2015-0080.

Ratna A, P., Naili, F., and Reni, S, D. (2012). Pengaruh Citra Destinasi, Fasilitas Wisata Dan Experiential Marketing Terhadap Loyalitas Melalui Kepuasan (Studi Pada Pengunjung Domestic Taman Wisata Candi Borobudur). Jurnal Ilmu Administrasi Bisnis.

Rizkiana, Y., and Kartini. (2017). Analisis Tingkat Financial Literacy dan Financial 
Behavior Mahasiswa S1 Fakultas Ekonomi Universitas Islam Indonesia. Efektif Jurnal Ekonomi Dan Bisnis, 7(1), 102-116.

Silvestri, C., Aquilani, B., and Ruggieri, A. (2017). Service Quality And Customer Satisfaction In Thermal Tourism. TQM Journal, 29(1), 55-81. https://doi.org/10.1108/TQM-06-2015-0089.

Sirait, H., and Puddin, K. (2018). Pengaruh Harga Dan Fasilitas Terhadap Keputusan Berkunjung Wisatawan Di Objek Wisata Bukit Gibeon Kecamatan Ajibata Kabupaten Toba Samosir. JURNAL PLANS : PENELITIAN ILMU MANAJEMEN DAN BISNIS, 13(1), 48-54. https://doi.org/DOI: https://doi.org/1.

Sugiyono. (2016). Metode Penelitian Kuantitatif, Kualitatif dan $R \& D$ ( ${ }^{\text {th }}$ ed.). Alfabeta.

Sumarwan. (2002). Perilaku Konsumen Teori Dan Penerapannya Dalam Pemasaran. Ghalia Indonesia.

Suryaningsih, I. B., and Sumani, S. (2018). The Influence of Financial Literacy, The Image of Destination, The Social Media Against The Interest of Visiting Lcal Tourists Through The Mediation of The Emotional Experience. European Journal of Management and Marketing Studies, 3(4), 1-18. https://doi.org/10.5281/zenodo.2542742.

Susanto, A, A., and T, S, M, R. (2017). Pengaruh Kualitas Pelayanan, Harga, Promosi Terhadap Kepuasan Wisatawan Dan Minat Kunjungan Kembali. Jurnal Manajemen Ekonomi Dan Bisnis Media Ekonomi, 17(2), 102-109.

Swani, K., and Yoo, B. (2010). Interactions between price and price deal. Journal of Product and Brand Management, 19(2), 143-152. https://doi.org/10.1108/10610421011033494.

Thai, V. V. (2008). Service quality in maritime transport : conceptual model and empirical evidence. 20(4), 493-518. https://doi.org/10.1108/13555850810909777.

Thai, V. V. (2015). The impact of port service quality on customer satisfaction: The case of Singapore. 1-18. https://doi.org/10.1057/mel.2015.19.

Utama, I. G. B. R. (2017). Pemasaran Pariwisata. ANDI.

Wahidin, D., and Purnhagen, K. (2018). Improving the level of food safety and market access in developing countries. Heliyon, January, e00683. https://doi.org/10.1016/j.heliyon.2018.e00683.

Wang, C. L., and Chen, Z. X. (2004). Consumer ethnocentrism and willingness to buy domestic products in a developing country setting : testing moderating effects. 21(6), 391-400. https://doi.org/10.1108/07363760410558663.

Wang, X., Zhang, J., Gu, C., and Zhen, F. (2009). Examining Antecedents and Consequences of Tourist Satisfaction: A Structural Modeling Approach. Tsinghua Science and Technology, 14(3), 397-406. https://doi.org/10.1016/S10070214(09)70057-4.

Ye, S., Xiao, H., and Zhou, L. (2019). Small accommodation Business Growth In Rural Areas: Effects On Guest Experience And Financial Performance. International Journal of Hospitality Management, 76(December 2017), 29-38. https://doi.org/10.1016/j.ijhm.2018.03.016.

Yuliandari, W. (2018). Kepuasan Konsumen Pengguna Jasa Paket Wisata Di PT Naifahduta Utama Tour Dan Travel Pekanbaru. JOM Fisip, 5(1), 1-11. 